\title{
EVALUASI SISTEM INFORMASI PENDAFTARAN PASIEN RAWAT JALAN DI RUMAH SAKIT UMUM PKU MUHAMMADIYAH BANTUL
}

\author{
Devy Haryadi, Solikhah \\ Fakultas Kesehatan Masyarakat, Universitas Ahmad Dahlan Yogyakarta
}

\begin{abstract}
ABSTRAK
Latar Belakang: Penerapan sistem informasi merupakan suatu cara untuk menunjang proses pelayanan pasien. SDM memiliki peranan yang penting didalam keberhasilan suatu sistem, disamping itu juga ditunjang dengan sarana dan prasarana yang memadai. RSU PKU Muhammadiyah Bantul sudah menerapkan sistem informasi di dalam proses pelayanan pasien, termasuk di dalam pelayanan pendaftaran pasien rawat jalan. Namun terdapat beberapa kendala didalam penerapannya, diantaranya seperti masalah SDM, sarana dan prasarana, serta laporan yang dihasilkan. Tujuan dari penelitian ini untuk Mengevaluasi Penerapan Sistem Informasi Pendaftaran Pasien Rawat jalan di RSU PKU Muhammadiyah Bantul.

Metode: Penelitian ini merupakan penelitian deskriptif kualitatif, yaitu untuk menggambarkan bagaimana penerapan sistem informasi pendaftaran pasien rawat jalan di RSU PKU Muhammadiyah Bantul. Teknik pengumpulan data dilakukan dengan cara wawancara, observasi, dan dokumentasi.

Hasil: RSU PKU Muhammadiyah menggunakan cara komputerisasi dan manual didalam proses pelayanan pendaftaran pasien rawat jalannya. Data yang dibutuhkan yaitu identitas pasien dan poli atau unit yang ingin dituju oleh pasien. Dana yang dibutuhkan berasal dari rumah sakit sendiri, dan tidak memiliki hambatan didalam pendanaan. Pengorganisasian tenaga kerjanya sudah terorganisasi dengan baik. Namun jumlah tenaga kerja yang sangat minim serta sarana komputer yang dianggap masih kurang, membuat tenaga kerja di bagian pendaftaran rawat jalan harus memikul beban kerja yang cukup besar. Hal tersebut mengakibatkan laporan jumlah pasien rawat jalan yang dihasilkan belum bisa dikatakan akurat, tepat waktu, dan relevan.
\end{abstract}

Kesimpulan: SDM dan sarana komputer masih kurang, sehingga menghasilkan informasi yang belum akurat, tepat waktu, dan relevan.

Kata Kunci: Evaluasi, Sistem Informasi di Bagian Pendaftaran Pasien Rawat Jalan, Rumah Sakit

\begin{abstract}
Background: The application of information sytem is a way to support the process of patient service. Human resources play the important part to certain the goal of a system, besides, it also must be supported by the enough of facility and infrastructure. PKU Muhammadiyah Hospital of Bantul have been applying the information system in the process of patient service, including to the outpatient registration service. However, there were some problems in that application, likes the problem of human resource, fasility and infrastructur, and the report. The purpose of this research was to evaluate the application of information system in outpatient registration at PKU Muhammadiyah Haspital of Bantul.

Methods: This research was descriptive study employed qualitative approach. The aim of this research was to describ the application of information system in outpatient registration at PKU Muhammadiyah Haspital of Bantul. Interview, observation, and documentation study were done to collect data.

Results: PKU Muhammadiyah Hospital of Bantul have been using the computer and manually to serve the outpatient registration. The data that were needed were the identity of patient, and the polyclinic or unit that the patient wanted to check their health. The source of cost operational
\end{abstract}


was from the estimate of the hostital it's self, and there was no problem about it. The organizing of staff was be orginized well. But, the number of staff and the computers are was not enough, that was cause the staff in the outpatient registration service got the job more than what they should. Because of that, the report for the total of outpatient was not accurate, timely basic, and relevance.

Conclusion: Human resourse and fasilities of computere were not enough, that was cause the report was not accurate, timely basic, and relevance.

Keyword: evaluation, information system, outpatient registration, hospital

\section{PENDAHULUAN}

Manusia dalam kehidupannya akan selalu berusaha melakukan apa saja demi memenuhi kebutuhannya. Secara naluri mereka akan menjaga kesehatan mereka dengan melakukan berbagai cara. Salah satu cara untuk dapat terus menjaga kesehatan adalah mendatangi rumah sakit yang memang dibangun dalam rangka memberikan pelayanan kesehatan pada masyarakat ${ }^{1}$. Sejalan dengan amanat Pasal $28 \mathrm{H}$, ayat (1) perubahan Undang-Undang Dasar Negara Republik Indonesia Tahun 1945 telah ditegaskan bahwa setiap orang berhak memperoleh pelayanan kesehatan, kemudian dalam Pasal 34 ayat (3) dinyatakan negara bertanggung jawab atas penyediaan fasilitas pelayanan kesehatan fasilitas pelayanan umum yang baik.

Rumah sakit sebagai salah satu fasilitas pelayanan kesehatan perorangan merupakan bagian dari sumber kesehatan yang sangat diperlukan dalam mendukung penyelenggaraan upaya kesehatan. Penyelenggaraan pelayanan kesehatan di rumah sakit mempunyai karakteristik dan organisasi yang sangat kompleks ${ }^{2}$. Peraturan Menteri Kesehatan RI No. 1171/MENKES/PER/VI/2011 dalam pasal 1 ayat (1) menyatakan bahwa setiap rumah sakit wajib melaksanakan sistem informasi rumah sakit (SIRS), dan ayat (2) yaitu SIRS sebagaimana dimaksudkan pada ayat (1) adalah suatu proses pengumpulan, pengolahan, dan penyajian data rumah sakit. Salah satu terobosan yang banyak digunakan di rumah sakit saat ini untuk meningkatkan efesien yaitu dengan menggunakan komputer di manajemen rumah sakit. Sistem informasi dapat digunakan sebagai sarana strategis untuk memberikan pelayanan yang berorientasi kepada kepuasan pelanggan. Komputer di rumah sakit dinilai sangat bermanfaat untuk meningkatkan mutu pelayanan. Selain untuk mempermudah pelayanan, sistem komputerisasi di rumah sakit tidak hanya digunakan di bagian administrasi khususnya di personalia, tetapi komputerisasi bisa digunakan di berbagai unit pelayanan di rumah sakit. Permasalahan yang ada di rumah sakit pada saat ini yaitu antara lain kurang berkesinambungan sistem informasi yang dihasilkan oleh pihak rumah sakit. Hal ini disebabkan salah satunya oleh sumber daya manusia yang belum memadai khususnya di bagian informasi ${ }^{3}$.

Sistem informasi manajemen rumah sakit khususnya di bagian pendaftaran yang ada di rumah sakit di Indonesia masih menggunakan sistem manual, meskipun sebagian rumah sakit juga sudah ada komputer di bagian pendaftaran tapi penggunaannya kurang maksimal, untuk mempermudah semua kegiatan di bagian pendaftaran, salah satu solusi didalam melaksanakan kegiatan manajemen informasi di rumah sakit, yaitu dengan memaksimalkan penggunaan sistem informasi pendaftaran dengan membuat atau memiliki software yang lebih lengkap isinya, termasuk di dalamnya sistem informasi di bagian pendaftaran rawat jalan ${ }^{3}$. Perkembangan rawat jalan rumah sakit sangat pesat, hal ini dipicu oleh sistem pembiayaan yang sangat menuntut efisiensi dan perkembangan teknologi kedokteran yang canggih yang memberikan kecepatan yang sangat signifikan ${ }^{4}$.

KESMAS Vol. 7, No. 2, September 2013: 55 - 
Rumah Sakit Umum PKU Muhammadiyah Bantul sudah menggunakan sistem komputerisasi didalam melayani pasien, termasuk di bagian pendaftaran pasien rawat jalan. Berdasarkan hasil wawancara yang dilakukan pada tanggal 10 Mei 2012 dengan Bapak Anwar, sebagai kepala bagian electronic data processing (EDP) yang bertempat di RSU PKU Muhammadiyah Bantul, RSU PKU Muhammadiyah Bantul sedang dalam proses pengembangan sistem, sehingga berdampak pada penerapan sistem informasi pendaftaran pasien rawat jalan, yaitu laporan jumlah pasien rawat jalan yang di-input ke dalam komputer oleh petugas pendaftaran, tidak bisa diakses oleh pihak rekam medis. Selain itu, juga terdapat beberapa kendala, seperti :

1. Kurangnya SDM atau tenaga kerja sehingga menimbulkan Overload pekerjaan bagi tenaga kerja, hal tersebut dilihat dari porsi program yang dikerjakan oleh para tenaga kerja di bagian sistem informasi pendaftaran tersebut.

2. Kurangnya sarana dan prasarana penunjang di dalam pengelolaan sistem informasi pendaftaran pasien rawat jalan.

Berdasarkan masalah yang timbul di bagian sistem informasi pendaftaran rawat jalan tersebut, oleh karena itu peneliti bermaksud melakukan penelitian untuk melakukan evaluasi Sistem Informasi Pendaftaran Pasien Rawat Jalan di RSU PKU Muhammadiyah Bantul.

\section{METODE PENELITIAN}

Jenis penelitian ini adalah penelitian deskriptif kualitatif. Penelitian ini memusatkan pada masalah-masalah yang bersifat aktual, terkait dengan penerapan sistem informasi pendaftaran pasien rawat jalan di Rumah Sakit Umum PKU Muhammadiyah Bantul. Penelitian ini berlangsung di Rumah Sakit Umum PKU Muhammadiyah Bantul, yang dilaksanakan mulai Bulan Juni 2012 dan berakhir pada Bulan Oktober 2012 . Subyek dalam penelitian ini adalah satu orang di bagian electronic data processing (EDP), dan dua orang tenaga kerja di bagian pengelola sistem informasi pendaftaran pasien rawat jalan di RSU PKU Muhammadiyah Bantul.

Instrumen penelitian yang digunakan pada penelitian ini adalah: 1) Pedoman wawancara yaitu untuk melakukan wawancara terbuka dengan Subyek Penelitian; 2) Panduan checklist yaitu untuk melakukan pengamatan langsung terhadap keadaan objek penelitian; 3) Alat tulis, Buku Catatan dan Recorder yaitu untuk menunjang proses wawancara dari informan (subyek penelitian). Variabel yang digunakan dalam penelitian ini adalah variabel tunggal yaitu evaluasi sistem informasi pendaftaran pasien rawat jalan.

\section{HASIL PENELITIAN DAN PEMBAHASAN}

\section{A. Hasil Penelitian}

\section{Gambaran Umum Rumah Sakit Umum PKU Muhammadiyah Bantul}

Rumah Sakit Umum PKU Muhammadiyah Bantul adalah rumah sakit swasta yang sedang berkembang yang ada di wilayah kota Bantul, tepatnya di Jl. Jendral Sudirman 124 Bantul. Rumah sakit ini didirikan pertama kali pada tanggal 1 Maret 1996, berawal dari sebuah Balai Pengobatan dan Rumah Sakit Bersalin yang kemudian pada tanggal 21 Agustus 1995 menjadi Rumah Sakit Khusus Ibu dan Anak, dan pada tahun 2001 resmi menjadi Rumah Sakit Umum type C dengan jumlah tempat tidur sebanyak 104. Jumlah karyawan tetap 278 orang, dan karyawan tidak tetap 124 orang. Jumlah Dokter Umum 14 orang, jumlah Dokter Spesialis 50 orang, dan jumlah Dokter Gigi lima orang. 
Rumah Sakit Umum PKU Muhammadiyah Bantul merupakan rumah sakit swasta milik Persyarikatan Muhammmadiyah telah berupaya untuk mengantisipasi kebutuhan dan tuntutan masyarakat akan pola pelayanan kesehatan dengan diberlakukan falsafah yang berbunyi "RSU PKU Muhammadiyah Bantul merupakan perwujudan dari ilmu, iman dan amal sholeh", dengan motto "Layananku Ibadahku", dan visi "Terwujudnya Rumah Sakit Islami yang mempunyai keunggulan kompetitif global dan menjadi kebanggaan umat" serta misi "Berdakwah melalui pelayanan kesehatan yang berkualitas dengan mengutamakan peningkatan kepuasan pelanggan serta peduli pada kaum dhu'afa".

\section{Karakteristik Informan}

\begin{tabular}{cccc}
\hline $\begin{array}{c}\text { Umur } \\
(\text { Tahun })\end{array}$ & Jenis Kelamin & Pendidikan & Jabatan \\
\hline 30 & Perempuan & D3 & Staff \\
25 & Perempuan & S1 & Staff \\
37 & Laki-Laki & S1 & EDP \\
\hline
\end{tabular}

3. Hasil Penelitian Sistem Informasi Pendaftaran Pasien Rawat Jalan di RSU PKU Muhammadiyah Bantul

a. Input

1) Data

Data yang dibutuhkan di bagian pendaftaran pasien rawat jalan adalah data pasien yang berobat. Pasien baru akan diminta untuk mengisi blangko rekam medis yang berisi identitas diri, yang kemudian akan dimasukkan di computer dan akan disimpan di rekam medis, kemudian pasien tersebut akan diberikan kartu berobat. Sedangkan bagi pasien lama hanya perlu menunjukkan kartu index berobat kepada petugas pendaftaran, kemudian memberitahukan poli atau unit yang mau dituju. Petugas akan memasukkan data-data tersebut ke dalam komputer yang kemudian bisa diakses oleh poli atau unit terkait.

2) Sumber Daya

a) Tenaga (SDM)

Sumber Daya Manusia (SDM) yang juga disebut sebagai user di sini merupakan tenaga kerja atau pegawai yang bertugas di bagian pelayanan pendaftaran pasien rawat jalan. Tenaga kerja di bagian pendaftaran dan filling berjumlah 15 orang, dan dibagi menjadi empat shift, dimana sistem kerjanya secara rolling antar di bagian pendaftaran dan di filling. Tenaga kerja di bagian pendaftaran ada dua sampai tiga orang setiap shift-nya. Satu tenaga kerja bertugas melayani askes, dan dua lainnya melayani pendaftaran pasien, serta sekaligus sebagai distributor, yang mengantar berkas rekam medis ke poli-poli atau unit-unit terkait. Tidak semua tenaga kerja di bagian pendaftaran merupakan lulusan D3, sebagian berasal dari SMA dan tenaga kerja kontrak, setiap tenaga kerja di bagian pendaftaran harus memiliki sertifikat belajar komputer, dan akan diorientasi selama satu minggu sebelum bekerja.

b) Biaya (Dana)

Biaya (dana) yang dibutuhkan oleh RSU PKU Muhammadiyah bantul untuk mengoperasikan seluruh kegiatan yang berhubungan dengan pelayanan sistem informasi pendaftaran

KESMAS Vol. 7, No. 2, September 2013 : 55 - 
pasien rawat jalan berasal dari rumah sakit sendiri. RSU PKU Muhammadiyah bantul merupakan rumah sakit swasta, sehingga seluruh biaya operasionalnya berasal dari rumah sakit sendiri tanpa ada bantuan dari pihak manapun, termasuk pemerintah.

c) Fasilitas

Fasilitas yang dimaksud di sini adalah sarana dan prasarana pendukung di dalam proses pelayanan pendaftaran pasien rawat jalan. Sarana di bagain pendaftaran berupa dua unit komputer rakitan dual core, software yang digunakan yaitu software program linux dengan Programming languages gambas. Dua unit komputer tersebut digunakan untuk proses pendaftaran pasien rawat jalan, rawat inap, dan IGD. Selain itu, juga terdapat dua unit printer, dan dua unit telfon. Berdasarkan hasil observasi, sarana dan prasarana yang berupa tempat atau ruangan di bagian pendaftaran kurang memadai, dapat dilihat dari tata letak komputer, telefon, dan printer yang berdekatan, serta ruang gerak tenaga kerja yang terbatas.

Unit yang bertanggung jawab terhadap kelancaran konsep system informasi serta bertugas dalam perawatan dan pemeliharaan software dan hardware komputer adalah tim electronic data processing (EDP). Perawatan dan pemeriksaan hardware dilakukan tiap tiga tahun sekali, namun apabila ada laporan kerusakan, maka tim EDP akan langsung melakukan perbaikan dan evaluasi. Sedangkan pada software, RSU PKU Muhammadiyah Bantul menggunakan program linux, sehingga bebas dari virus.

\section{b. Process}

1) Pengorganisasian

Pengorganisasian disini merupakan suatu kegiatan pembagian tugas kepada tiap-tiap petugas, tenaga kerja di bagian pendaftaran dan di bagian filing berjumlah 15 orang, dimana mereka bekerja secara rolling antar di bagian pendaftaran dengan filing. Setiap shift-nya ada dua sampai tiga tenaga kerja. Satu tenaga kerja menangani bagian pelayanan askes, dan yang lainnya melayani bagian pendaftaran dan distribusi ke poli-poli atau unit yang dituju.

2) Pengolahan Data

Pengolahan data di bagian pendaftaran pasien rawat jalan dilakukan dengan komputerisasi dan manual.

a) Untuk pasien baru, begitu pasien datang, petugas pendaftaran akan mencatat data pasien, kemudian akan di-entry ke dalam komputer. Petugas akan membuat kartu berobat untuk pasien, yang bisa digunakan apabila sewaktu-waktu datang untuk berobat kembali. Setelah itu, petugas akan memasukkan data-data pasien dan diakses ke poli atau unit yang ingin dituju oleh pasien. Petugas akan memberikan nomor urut panggilan kepada pasien untuk diberikan kepada perawat di poli atau unit yang terkait. Sementara itu, petugas pendaftaran akan mencetak data pasien di lembar rawat jalan lalu memasukkan lembar rawat jalan tersebut ke dalam berkas rekam medis, dan didistribusikan ke poli atau unit yang dituju oleh pasien.

b) Untuk pasien lama, pasien hanya perlu menunjukkan kartu berobat, kemudian petugas pendaftaran akan mencari data di dalam computer dengan memasukkan nama dan nomor rekam medisnya, setelah ditemukan, data tersebut akan diakses ke bagian filing 
untuk diambilkan berkas rekam medisnya. Berkas rekam medis tersebut akan didistribusikan ke poli atau unit yang dituju oleh pasien serta memberikan nomor urut panggilan kepada pasien, untuk diberikan kepada perawat di poli atau unit terkait.

\section{c. Output}

Output yang dihasilkan sangat bergantung dari komponen input dan process-nya, apabila komponen input dan process-nya baik dan mendukung, maka akan menghasilkan output yang baik pula, begitu juga sebaliknya. Penggunaan komputer di bagian pendaftaran sangat membantu dalam proses mempercepat pelayanan pasien. Output atau keluaran dari penerapan sistem informasi pendaftaran pasien rawat jalan, dapat berupa jumlah pasien rawat jalan, baik pasien baru maupun pasien lama, diantaranya adalah pasien IGD, poliklinik, laboratorium, radiologi, dan farmasi. Selain itu, keluarannya juga berupa informasi yang dapat diberikan kepada poli-poli atau unit-unit terkait sesuai dengan tujuan pasien, serta dapat menjadi laporan bulanan yang dilakukan oleh bagian rekam medis.

\section{B. Pembahasan}

\section{Input}

a) Data

Berdasarkan hasil penelitian, data yang dibutuhkan di bagian pendaftaran rawat jalan adalah data identitas pasien, seperti nama, alamat, umur, jenis kelamin, dan sebagainya. Petugas pendaftaran akan langsung meminta data kepada pasien baru, data yang diberikan oleh pasien harus sesuai dengan yang tertera di kartu tanda penduduk (KTP) si pasien, petugas pendaftaran juga harus memeriksa hal tersebut. Selain itu, petugas juga membutuhkan data berupa poli atau unit yang ingin dituju oleh pasien, serta terkadang pasien juga meminta dokter tertentu untuk memeriksanya, hal tersebut juga merupakan data yang dibutuhkan oleh petugas pendaftaran pasien rawat jalan bagi pasien baru. Sedangkan untuk pasien lama, data yang dibutuhkan berasal dari buku rekapan rekam medis yang sudah tersimpan di bagian filing rekam medis. Pasien hanya harus menunjukkan kartu berobat, dimana di dalamnya sudah terdapat nama dan nomor rekam medis pasien. Petugas akan membutuhkan data rekam medis pasien yang ada di bagian filing sesuai dengan nama dan nomor rekam medis yang ada di kartu berobat rekam medis pasien tersebut. Sumber data adalah dari mana data berasal. Sumber data dapat terdiri dari sumber data primer dan sumber data sekunder. Sumber data primer adalah data yang didapatkan langsung dari pihak pertama. Sedangkan sumber data sekunder adalah data yang didapatkan dari sumber lain ${ }^{5}$.

b) Sumber Daya

1) Tenaga (SDM)

Sumber Daya Manusia (SDM) atau petugas di bagian pendaftaran dan filing berjumlah 15 orang, dimana antar petugas pendaftaran dan filing bekerja secara rolling, dan dibagi menjadi empat shift. Petugas di bagian pendaftaran sendiri, setiap shift terdiri dari dua sampai tiga orang. Satu orang melayani askes, sementara dua lainnya melayani pendaftaran sekaligus sebagai distributor, yang bertugas mengantar berkas rekam medis ke poli atau unit terkait. Melihat hal tersebut, jumlah tenaga kerja di bagian pendaftaran bisa dikatakan 
masih kurang, karena dengan dua petugas, mereka harus melayani pendaftaran pasien, sekaligus sebagai distributor yang harus mengantar berkas rekam medis ke poli-poli atau unit terkait, sehingga menimbulkan beban kerja yang berlebihan bagi tenaga kerja di bagian pendaftaran tersebut. sumber daya manusia (SDM) merupakan salah satu komponen penting dalam pelayanan rumah sakit. Manajemen profesional sangat dibutuhkan untuk menentukan kualitas sumber daya manusia dalam memberikan pelayanan rumah sakit yang berkualitas ${ }^{6}$.

Tenaga kerja di bagian sistem informasi pendaftaran pasien rawat jalan, tidak semua merupakan lulusan D3 atau $\mathrm{S} 1$, sebagian berasal dari lulusan SMA, namun seluruh tenaga kerja tersebut harus memiliki latar belakang pendidikan komputer, minimal memiliki sertifikat belajar komputer. Untuk tenaga kerja baru tidak diberikan pelatihan khusus, hanya diorientasi selama satu minggu untuk melihat sejauh mana kemampuan mereka dalam menjalankan sistem pada komputer.

2) Biaya (dana)

RSU PKU Muhammadiyah Bantul merupakan rumah sakit swasta, jadi biaya operasionalnya berasal dari rumah sakit sendiri, termasuk untuk membiayai seluruh kegiatan yang berkaitan dengan penerapan sistem informasi pendaftaran pasien rawat jalan, tanpa ada bantuan dari pihak lain. Sistem anggaran merupakan sistem yang menyediakan informasi untuk perencanaan-perencanaan manajemen. Suatu anggaran (budget) digunakan untuk memproyeksikan sumber daya perusahaan di masa mendatang ${ }^{7}$.

Anggaran pendapatan dan pengeluaran rumah sakit akan diakumulasi dan dibuat laporan setiap tahun. Dana untuk perbaikan dan pengadaan fasilitas yang dibutuhkan oleh bagian pendaftaran juga berasal dari anggaran tersebut. Selama ini RSU PKU Muhammadiyah Bantul mempunyai sumber dana yang cukup untuk biaya seluruh proses operasionalnya.

3) Fasilitas

Berdasarkan penelitian yang dilakukan, di bagian pendaftaran, terdapat dua unit komputer rakitan dual core, software yang digunakan yaitu software program linux dengan Programming languages gambas. Proses input data untuk pendaftaran pasien rawat jalan, rawat inap, dan IGD, dilakukan dengan komputer yang sama. Dua buah komputer di bagian pendaftaran tersebut bisa dibilang masih kurang, minimal di bagian pendaftaran harus ada tiga buah komputer, agar proses pendaftaran pasien rawat jalan, rawat inap, dan IGD, bisa dilakukan dengan dengan komputer yang terpisah dan dengan tenaga kerja yang berbeda pula. Sementara itu, di bagian pendaftaran juga memiliki dua buat printer dan dua buat telefon, dengan jumlah tersebut, bisa dibilang sudah mencukupi. Teknologi merupakan kotak alat (tool-box) dalam sistem informasi. Teknologi digunakan untuk menerima input, menjalankan model, menyimpan dan mengakses data, menghasilkan dan mengirimkan keluaran dan membantu pengendalian dan sistem secara keseluruhan ${ }^{7}$. Sedangkan prasarananya masih kurang memadai, hal tersebut dapat dilihat dari tempat atau ruangan yang kecil untuk bagian pendaftaran, sehingga menyebabkan tata letak komputer, telefon, dan printer yang berdekatan, selain itu ruang atau tempat untuk pelayanan pendaftaran juga menjadi satu dengan pelayanan informasi, sehingga membuat ruang gerak tenaga kerjanya terbatas. 
RSU PKU Muhammadiyah Bantul sendiri memiliki tim khusus yang bertanggung jawab atas kelancaran sistem, perawatan serta pemeliharaan sarana yang ada, yaitu bagian EDP. Tim EDP melakukan pemeriksaan dan perawatan hardware komputer secara berkala, yaitu setiap tiga tahun. Sedangkan untuk perawatan software, tim EDP tidak mengalami kesulitan, karena rumah sakit sendiri menggunakan linux, sehingga bebas dari virus. Namun apabila ada laporan kerusakan dari berbagai pihak, tim EDP akan langsung memperbaiki, jika sudah tidak bisa diperbaiki, maka akan langsung diganti dengan melihat anggaran dana yang ada.

\section{Process}

\section{a) Pengorganisasian}

Pengorganisasian adalah pembagian tugas kepada setiap tenaga kerja di bagian sistem informasi pendaftaran pasien rawat jalan. Jumlah tenaga kerja di bagian pendaftaran dan di filing berjumlah 15 orang, dimana satu shift ada empat sampai lima orang, antara bagian pendaftaran dan filing bertugas secara rolling, jika dalam satu shift terdapat lima orang, dua orang akan bertugas di bagian filing, tiga orang di bagian pendaftaran, untuk di pendaftaran sendiri, satu orang bertugas dalam pelayanan askes, sementara dua orang melayani pendaftaran dan distribusi status ke poli atau unit yang dituju oleh si pasien. Pembagian tugas di bagian pendaftaran tersebut sudah terorganisir dengan baik, dan setiap tenaga kerja sudah bisa melakukan tugasnya dengan cukup baik sesuai porsi kerjanya.

b) Pengolahan data

Pengolahan data di bagian pendaftaran pasien rawat jalan di RSU PKU Muhammadiyah Bantul dilakukan dengan dua cara, yaitu secara komputerisasi dan manual. Pengolahan data secara komputerisasi dilakukan dengan bantuan perangkat komputer, dengan cara meng-input data pasien ke dalam komputer, kemudian diakses ke poli atau unit yang dituju. Sementara secara manual, yaitu petugas pendaftaran mencatat data pasien untuk berkas rekam medis, sehingga apabila terjadi kesalahan di dalam sistem yang mengakibatkan kehilangan data, terutama data pasien, maka masih ada data tertulis yang tersimpan di dalam berkas rekam medis. Pengolahan data adalah kegiatan untuk mengubah sejumlah data yang didapat menjadi suatu bentuk yang dapat dianalisis dan diinterpretasikan ${ }^{5}$. Pengolahan data dapat dilakukan secara manual, tetapi dengan kemajuan teknologi dan ilmu pengetahuan, pengolahan data umumnya dilakukan secara komputerisasi.

Allah SWT juga menganjurkan kepada kita untuk mencatat apa yang kita kerjakan, seperti yang diterangkan di dalam QS. Al-Jaatsiyah (45; 29), yang artinya: (Allah berfirman): "Inilah kitab (catatan) Kami yang menuturkan terhadapmu dengan benar. Sesungguhnya Kami telah menyuruh mencatat apa yang telah kamu kerjakan". Firman Allah SWT tersebut telah menjelaskan kepada kita agar mencatat apa yang telah kita kerjakan. Sama halnya dengan proses pengolahan data di bagian pendaftaran pasien rawat jalan di sini. Selain menggunakan proses komputerisasi, juga dibutuhkan proses manual, untuk mengantisipasi apabila terjadi kesalahan pada komputer yang akan mengakibatkan kehilangan data-data pasien. 


\section{Output}

Output yang dihasilkan dari penerapan sistem informasi pendaftaran pasien rawat jalan yaitu berupa laporan jumlah pasien IGD, yang di dalamnya berisi, dokter yang memeriksa, tidakan yang didapat oleh pasien, dan diagnosanya. Selain itu output dari pendaftaran berupa status atau datadata pasien yang diakses ke poli atau unit terkait. Kualitas suatu informasi (quality of information) tergantung dari tiga hal, yaitu informasi yang akurat (accurate), tepat pada waktunya (timely basis) dan relevan (relevance) ${ }^{7}$. Berdasarkan hasil penelitian yang telah dilakukan, RSU PKU Muhammadiyah tidak memiliki SOP secara tertulis khusus untuk sistem informasi. Output yang dihasilakan dari penerapan sistem informasi pendaftaran pasien rawat jalan belum bisa dibilang akurat, tepat waktu,dan relevan.

a) Belum akurat, karena laporan pasien IGD yang ditulis di berkas rekam medis terkadang berbeda dengan yang di-input dikomputer oleh petugas pendaftaran, hal tersebut dikarenakan kurangnya tenaga kerja yang harus menangani pelayanan pendaftaran, dimana tenaga kerjanya berjumlah dua orang, dan harus melayani pendaftaran pasien rawat jalan, rawat inap, dan IGD. Selain itu, pasien IGD juga merupakan pasien yang harus ditangani dengan segera, hal tersebut juga menunjang dalam ketidak-akuratannya data yang ditulis atau yang dimasukkan ke dalam komputer, karena kerja petugas pendaftaran yang dituntut untuk tindakan yang cepat pada pasien IGD, sedangkan mereka juga harus melayani pendaftaran pasien lain, serta distributor. Sehingga dalam hal ini, petugas bagian penerima laporan, yaitu di bagian administrasi rekam medis harus memeriksa ulang laporan dari petugas pendaftran.

b) Belum tepat waktu, karena tenaga kerja di bagian pendaftaran juga sekaligus merangkap sebagai distributor, jadi pada saat data pasien diakses ke poli atau unit yang dituju oleh pasien, poli atau unit terkait sudah bisa mengakses data tersebut, namun terkadang berkas rekam medisnya belum ada, hal tersebut juga disebabkan oleh kurangnya tenaga kerja di bagian distributor, sehingga petugas pendaftaran yang berjumlah dua orang tersebut harus berfungsi ganda sebagai pelayanan pendaftaran serta sebagai pengantar berkas rekam medis ke poli atau unit terkait.

c) Belum relevan, karena pada saat laporan jumlah pasien IGD dimasukkan ke dalam komputer oleh petugas pendaftaran, dan masuk ke data server, laporan tersebut akan bisa diakses oleh pihak manapun, termasuk pihak rekam medis untuk dibuat laporan bulanan. Namun pada saat sekarang ini, RSU PKU Muhammadiyah Bantul sedang dalam proses pengembangan sistem, dan belum sempurna. Hal tersebut berdampak kepada laporan yang di-input oleh petugas pendaftaran tidak bisa diakses oleh pihak rekam medis, jadi untuk sementara, pihak rekam medis harus meminta langsung laporan jumlah pasien ke bagian EDP sebagai penanggung jawab server, kemudian pihak EDP akan memberikan laporan jumlah pasien kepada pihak rekam medis dalam bentuk powerpoint. Hal tersebut akan bisa teratasi apabila proses pengembangan sistem yang dilakukan oleh EDP telah berjalan dengan sempurna. 


\section{SIMPULAN DAN SARAN}

\section{A. Simpulan}

Hasil dari penelitian tentang Evaluasi Sistem Informasi Pendaftaran Pasien Rawat Jalan di RSU PKU Muhammadiyah Bantul, dapat disimpulkan sebagai berikut :

1. Input

a) Data yang dibutuhkan yaitu identitas pasien dan poli atau unit serta dokter yang ingin dituju oleh pasien.

b) SDM di bagian pendaftaran masih kurang, karena petugas pelayanan pendaftaran sekaligus merangkap sebagai distributor berkas rekam medis.

c) Pendanaan untuk seluruh kegiatan penerapan sistem informasi pendaftaran pasien rawat jalan berasal dari rumah sakit sendiri, dan tidak ada masalah di dalam pendanaan.

d) Jumlah sarana komputer masih kurang dan prasarananya masih belum memadai.

2. Process

a) Pembagian tugas di bagian pendaftaran sudah baik

b) Proses pengolahan data dilakukan dengan dua cara, yaitu dengan komputerisasi dan manual.

\section{Output}

Informasi yang dihasilkan belum bisa dikatakan akurat, tepat waktu, dan relevan.

\section{B. Saran}

Berdasarkan hasil penelitian, saran-saran yang dapat disampaikan adalah sebagai berikut:

1. Menambah tenaga kerja (SDM) di bagian pendaftaran pasien rawat jalan agar tidak menimbulkan beban kerja yang berlebihan bagi tenaga kerjanya, terutama mengadakan petugas khusus untuk di bagian distributor berkas rekam medis.

2. Menambah unit komputer, agar data dan transaksi pendaftaran pasien rawat jalan, IGD, dan rawat inap dilakukan dengan komputer yang terpisah, bukan dalam komputer yang sama.

3. Perawatan, pemeriksaan, dan pemeliharaan software dan hardware seharusnya dilakukan setiap tahun, tidak hanya dilakukan setiap terjadi insidental atau menunggu laporan kerusakan.

\section{DAFTAR PUSTAKA}

1. Kembaren, S.B., Praptiningsih, Y.E., Nuraningsih,D., dan Warmansyah, J., Optimalisasi Rancangan Sistem Informasi Rawat Inap Menggunakan DFD-ERD Dikombinasikan dengan User Interface di Rumah Sakit Ibu dan Anak Budhi Jaya Jakarta, Jurnal Informatika Komputer, Volume 13 No. 1, Jakarta, 2008.

2. Kementrian Republik Indonesia, Keputusan Menteri Kesehatan RI Nomor : 129/MENKES/SK/II/2008 tentang Standar Pelayanan Minimal Rumah Sakit, 2008.

3. Rustiyanto, E., Sistem Informasi Manajemen Rumah Sakit yang Terintegrasi, Gosyen Publishing, Yogyakarta, 2010.

4. Sabarguna, B.S., Sistem Informasi Manajemen Rumah Sakit, Konsorsium, Yogyakarta, 2004.

5. Bustami, Penjaminan Mutu Pelayanan Kesehatan \& Akseptabilitasnya, Erlangga, Jakarta, 2011. 
6. Suharyono, M.W., Adisasmito, W.B.B., Analisis Jumlah Kebutuhan Tenaga Pekarya dengan Work Sampling di Unit Layanan Gizi Pelayanan Kesehatan, Jurnal Aplikasi Informasi, Volume 9 No. 2, Jakarta, 2006.

7. Jogiyanto, Sistem Informasi Berbasis Komputer, BPFE, Yogyakarta, 1997. 
